\title{
Rekonstruksjonslovens muligheter og begrensninger
}

Sjur Swensen Ellingsæter og Marie Meling*

Sammendrag: Rekonstruksjonsloven ble 7. mai 2020 vedtatt som en midlertidig lov, et hastetiltak for å forebygge «unødige» konkurser som følge av covid-19. Artikkelen diskuterer i hvilken utstrekning loven kan benyttes til å gjøre midlertidige og permanente endringer i gjeldsforpliktelsene til aksje- eller allmennaksjeselskaper med betalingsvansker. Artikkelen identifiserer også forhold som innebærer at rekonstruksjonsforhandlinger ikke alltid vil være den foretrukne løsningen. I tillegg pekes det på de grunnleggende interesseavveiningene som gjelder ved utformingen av rekonstruksjonsregler. Disse interesseavveiningene vil stå sentralt ved den fremtidige reformen av regelverket som vil måtte gjennomføres når rekonstruksjonsloven opphører 1. januar 2022 og EUs restruktureringsdirektiv trolig blir en del av EØSavtalen.

Nøkkelord: rekonstruksjon, gjeldsforhandling, konkurs, tvangsakkord, pant, insolvens, likviditet, konsern, kontrakt, aksjer

* Sjur Swensen Ellingsæter (født 1988) er førsteamanuensis ved Handelshøyskolen BI, Institutt for rettsvitenskap og styring.

Marie Meling (født 1982) er doktorgradsstipendiat ved Universitetet i Oslo, Nordisk institutt for sjørett.

\section{$1 \quad$ Innledning ${ }^{1}$}

Den 11. mai 2020 trådte rekonstruksjonsloven (rkl.) i kraft. ${ }^{2}$ Formålet med loven er å «redusere risikoen for unødige konkurser i levedyktige virksomheter som er rammet av en akutt svikt i inntektene som følge av utbruddet [av covid-19]». ${ }^{3}$ Virkemiddelet er å gi gjeldstyngede bedrifter tilgang til rekonstruksjonsforhandlinger. Slike forhandlinger setter kreditorrettigheter midlertidig ut av kraft og muliggjør permanente endringer i skyldnerens forpliktelser uten samtykke fra samtlige berørte kreditorer: Så lenge rekonstruksjonsforhandlingene pågår, begrenses sikrede og usikrede kreditorers adgang til å håndheve kravene sine mot skyldneren. Loven åpner dessuten for at skyldneren i en viss utstrekning kan tilby nye långivere pant $\mathrm{i}$ skyldnerens eiendeler på bedre prioritet enn eksisterende panthavere, i strid med panterettens

\footnotetext{
${ }^{1}$ Forfatterne takker professor emeritus Kåre Lilleholt og redaktør Amund B. Tørum for nyttige innspill. Feil og mangler står for forfatternes regning.

${ }^{2}$ Midlertidig lov 7. mai 2020 nr. 38 om rekonstruksjon for å avhjelpe økonomiske problemer som følge av utbrudd av covid-19. Alle paragrafhenvisninger i teksten er til denne loven, med mindre noe annet presiseres.

${ }^{3}$ Innst. 244 L (2019-2020) s. 1.
} 
utgangspunkt om tidsprioritet. Gjennom reglene om tvangsakkord åpner loven også for at et flertall av skyldnerens kreditorer kan godta et forslag om betalingsutsettelse eller gjeldslettelse med bindende virkning for $\varnothing$ vrige kreditorer.

Ettersom rekonstruksjonsloven ble til gjennom en meget rask og summarisk lovgivningsprosess, ble loven vedtatt som en midlertidig lov som opphører 1. januar 2022. ${ }^{4}$ Så lenge loven er i kraft, erstatter dens bestemmelser konkurslovens regler om gjeldsforhandling. ${ }^{5}$ Disse reglene ble vedtatt i 1984, og har siden vært gjenstand for få endringer og lite ros. ${ }^{6}$ Gjeldsforhandlingsreglene har vært lite brukt, ${ }^{7}$ og er nok av den grunn også lite beskrevet i nyere norsk litteratur. $^{8}$

Denne artikkelen har tre formål. Det første er å gi en oversikt over i hvilke tilfeller aksje- eller allmennaksjeselskaper med betalingsvansker kan benytte rekonstruksjonsforhandlinger til å gjøre midlertidige og permanente endringer i gjeldsforpliktelsene sine. ${ }^{9}$ For det andre vil vi peke på forhold som kan medføre at rekonstruksjonsforhandlinger etter rekonstruksjonsloven ikke trenger å være den foretrukne løsningen for slike selskaper. Ved å peke på det som - sett med skyldnerens $\varnothing y n e$ - kan oppfattes som svakheter ved regelverket, oppnår vi også artikkelens tredje formål: å belyse interesseavveiningene som gjør seg gjeldende ved utformingen av rekonstruksjonsregler.

Disse interesseavveiningene vil aktualiseres i nær fremtid. For det første er rekonstruksjonsloven, som nevnt, midlertidig, og Stortinget må innen utløpet av 2021 treffe ett av tre valg: å gjøre loven permanent, å la reglene om gjeldsforhandling gjeninnføres, eller å vedta et nytt regelverk. I tillegg vil trolig Norge, som antydet, bli underlagt EØS-rettslige krav om skyldneres tilgang til rekonstruksjonsforhandlinger. EU vedtok sommeren 2019 et direktiv om rekonstruksjon og insolvens. ${ }^{10}$ Direktivet krever at medlemslandene gir juridiske personer som er eller trolig vil bli insolvente, tilgang til et rammeverk for tidlig rekonstruksjon. ${ }^{11}$ I tillegg

\footnotetext{
${ }^{4}$ Prop. 75 L (2019-2020) s. 7 og rkl. § 64 annet ledd.

${ }^{5}$ Lov 8. juni $1984 \mathrm{nr} .58$ om gjeldsforhandling og konkurs (kkl.) § 1 .

${ }^{6}$ Se eksempelvis Aksel O. Hillestad, «Gjeldsforhandlinger for PGS - et bevis på norsk insolvenslovgivnings utilstrekkelighet?» Tidsskrift for forretningsjus 2007, s. 50-75.

${ }^{7}$ Konkursregisterets database inneholder 24 kunngjøringer om åpning av gjeldsforhandling i perioden 1 . januar 2010 til 27. august 2020.

${ }^{8}$ Kristian Husers Gjeldsforhandling og konkurs. Bind 1, Bergen 1987, gir fortsatt den mest utførlige fremstillingen av reglene.

${ }^{9}$ Når artikkelen benytter termene «selskap» og «skyldner», siktes det til aksje- og allmennaksjeselskaper.

${ }^{10}$ Directive (EU) 2019/1023 of 20 June 2019 on preventive restructuring frameworks, on discharge of debt and disqualifications, and on measures to increase the efficiency of procedures concerning restructuring, insolvency and discharge of debt, and amending Directive (EU) 2017/1132.

${ }^{11}$ Artikkel 1(1) bokstav a.
} 
gjelder det krav til innholdet i slike nasjonale rammeverk. Direktivet betegnes som EØSrelevant, men er foreløpig ikke tatt inn i EØS-avtalen. ${ }^{12}$ Justis- og beredskapsdepartementet kunngjorde nylig at det vurderer om det skal foreslå permanente regler om rekonstruksjon. ${ }^{13}$ Det fremstår som uavklart hvordan lovarbeidet skal foregå og om lovforslaget skal utformes i tråd med direktivets krav.

Av plasshensyn avgrenses det mot spørsmålet om i hvilken grad en norsk rekonstruksjon vil anerkjennes i andre land.

\section{$2 \quad$ Fra akkordforhandling til rekonstruksjon}

I utgangspunktet omfattes alle typer skyldnere av virkeområdet til rekonstruksjonsloven. I forarbeidene drøftet Justis- og beredskapsdepartementet om reglenes anvendelsesområde burde begrenses til «aktive næringsdrivende», men kom til at det ikke var nødvendig. ${ }^{14}$ Dermed kan i prinsippet både selskaper og enkeltpersoner bli underlagt rekonstruksjonsforhandlinger. For enkeltpersoner vil det i praksis være mer hensiktsmessig å søke gjeldsordning etter gjeldsordningsloven. ${ }^{15}$ For de enkeltpersonene som er avskåret fra å få gjeldsordning, ${ }^{16}$ kan det imidlertid være aktuelt å benytte seg av rekonstruksjonsforhandlinger.

Lovgiver har siden vedtagelsen av akkordforhandlingsloven ${ }^{17}$ i 1899 lagt til rette for at personer og selskaper med økonomiske problemer skal ha tilgang til akkord, både som et alternativ til konkurs og som et alternativ til utenrettslige forhandlinger med sine kreditorer. Med virkning fra 1. januar 1986 erstattet konkurslovens regler om gjeldsforhandling de tidligere akkordforhandlingsreglene. ${ }^{18}$ Gjeldsforhandlingsreglene ble endret igjen med virkning fra 1. januar 2000. Disse lovendringene hadde sitt utspring i et lovforslag utarbeidet av Falkangerutvalget, som mellom 1990 og 1993 utførte etterkontroll med konkurslovgivningen på oppdrag fra Justisdepartementet. ${ }^{19}$

\footnotetext{
${ }^{12}$ Per 29. september 2020, se https://www.efta.int/eea-lex/32019L1023.

${ }^{13}$ Se https://www.regjeringen.no/no/aktuelt/onsker-innspill-for-a-redde-flere-bedrifter/id2770132/

${ }^{14}$ Prop. 75 L (2019-2020) s. 21 flg.

${ }^{15}$ Lov 17. juli 1992 nr. 99 om frivillig og tvungen gjeldsordning for privatpersoner (gjeldsordningsloven eller gol.).

${ }^{16}$ Dvs. de som til tross for betalingsudyktighet ikke har opphørt med å drive næringsvirksomhet gjennom enkeltpersonforetak, jf. gol. $\S 1-2$.

${ }^{17}$ Lov 6. mai $1899 \mathrm{nr} .1$ om akkordforhandling (opphevet ved lov 8. juni $1984 \mathrm{nr}$. 60 om ikrafttredelse av ny gjeldsforhandlings- og konkurslovgivning m.m.).

${ }^{18}$ Lov 8. juni 1984 nr. 58 om gjeldsforhandling og konkurs (kkl.) første del.

${ }^{19}$ NOU 1993: 16 ble fulgt opp i Ot.prp. nr. 26 (1998-1999) samt i Ot.prp. nr. 23 (2003-2004), men endringene i den sistnevnte proposisjonen hadde ingen betydning for reglene om gjeldsforhandling.
} 
Rekonstruksjonsloven bygger i stor grad på en enkeltmannsutredning av dommer Leif VillarsDahl i 2016. ${ }^{20}$ Den terminologiske endringen fra «gjeldsforhandling» til «rekonstruksjon» er ment å reflektere at det ved rekonstruksjon «er tale om en nødvendig omlegging (rekonstruksjon) av virksomheten og måten den drives på, hvor en sanering av gjelden bare er en del av løsningen». ${ }^{21}$

Rekonstruksjonsloven bygger imidlertid fortsatt på mange av de samme grunnprinsippene som gjeldsforhandlingsreglene, som igjen bygget på akkordforhandlingsloven fra 1899. I en viss forstand fremstår dermed rekonstruksjonsloven som gammel vin på nye flasker. Den videre fremstilling vil vise at en rekonstruksjon - i likhet med gjeldsforhandling - først og fremst gir adgang til gjeldssanering av skyldnerens usikrede og uprioriterte gjeldsforpliktelser, og i liten grad gjør det mulig å gjøre inngrep i skyldnerens øvrige forpliktelser som pantesikrede krav og tyngende kontraktsforpliktelser.

\section{Rekonstruksjonsprosessen}

\section{1 Åpningsvilkår}

Rekonstruksjonsforhandlinger åpnes av retten. Rettens beslutning treffes etter begjæring fra skyldneren eller en kreditor. Etter konkurslovens regler er det derimot kun skyldneren som kan begjære åpning av gjeldsforhandling. I aksje- og allmennaksjeselskaper fremsettes begjæringen av styret, se aksjeloven (asl.) og allmennaksjeloven (asal.) § 6-18 første ledd. ${ }^{22}$

Vilkårene for åpning av rekonstruksjonsforhandlinger avhenger av hvem som fremsetter begjæringen. Hvis skyldneren fremsetter begjæringen, er vilkåret i $§ 2$ første ledd at skyldneren «har eller i overskuelig fremtid vil få alvorlige økonomiske problemer» (våre uthevinger). Denne utformingen skiller seg noe fra vilkåret for åpning av gjeldsforhandling etter konkursloven, nemlig kravet om illikviditet - at skyldneren «ikke kan oppfylle sine forpliktelser etter hvert som de forfaller». ${ }^{23}$

Endringene i ordlyden og uttalelser i forarbeidene tyder på at terskelen for åpning av rekonstruksjonsforhandlinger er ment å være lavere enn for åpning av gjeldsforhandlinger. ${ }^{24}$ End-

\footnotetext{
${ }^{20} \mathrm{Se}$ «Rekonstruksjon i turbulente tider - dynamiske virkemidler ved økonomiske problemer», utredning datert 29. februar 2016 (heretter «Utredningen»).

${ }^{21}$ Prop. 75 L (2019-2020) s. 12. «Rekonstruksjon» er i tillegg et godt innarbeidet begrep for lignende forhandlinger i svensk og dansk rett.

${ }^{22}$ Lov 13. juni $1997 \mathrm{nr} .44$ om aksjeselskaper og lov 13. juni $1997 \mathrm{nr}$. 45 om allmennaksjeselskaper.

${ }^{23}$ Konkursloven $\S 1$ a.

${ }^{24}$ Utredningen s. 34.
} 
ringen bygger på en tanke om at det er større sannsynlighet for at rekonstruksjonsforhandlinger lykkes hvis de igangsettes $f \phi r$ skyldneren har blitt illikvid. ${ }^{25}$

At konkurslovens illikviditetsvilkår nå er erstattet av den mer skjønnsmessige henvisningen til faktiske eller forventede alvorlige økonomiske problemer, trenger imidlertid ikke å innebære noen stor forskjell i praksis. Det har jo lenge vært antatt at en skyldner kan være illikvid selv om vedkommende ennå ikke har misligholdt betalingsforpliktelser. I illikviditetsvurderingen skal det nemlig også tas hensyn til evnen til å oppfylle betalingsforpliktelser som først forfaller i fremtiden, slik at vurderingen der også er fremadskuende. ${ }^{26}$

Villars-Dahls forslag om å endre åpningsvilkåret synes derimot å bygge på en forutsetning om at bare mer nær forestående fremtidige betalingsmislighold vil oppfylle vilkåret om illikviditet. I utredningen uttales det nemlig at betalingsmislighold «som ligger særlig lenger enn seks måneder frem i tid, vanskelig vil gi grunnlag for å åpne gjeldsforhandling». ${ }^{27}$ Det er ikke gitt at forståelsen av illikviditetsvilkåret, som altså danner premisset for endringen, er riktig. Ordlyden i kkl. $\S 1$ a tilsier ikke at man kun skal se hen til mislighold innenfor en så begrenset tidshorisont som seks måneder. Etter vårt syn er alle fremtidige betalingsmislighold relevante så fremt de med tilstrekkelig grad av sikkerhet vil inntre. Hvis det kan sannsynliggjøres at skyldneren ikke vil kunne betale et lån når det forfaller om tre år, kan derfor illikviditetsvilkåret være oppfylt. En annen sak er at det i praksis normalt vil være enklere å sannsynliggjøre betalingsmislighold som er nær forestående, enn betalingsmislighold som ligger et stykke frem i tid.

Ved vurderingen av om skyldneren allerede skal anses som illikvid, vil retten i stor grad måtte bygge på informasjon og vurderinger gitt av skylderen selv. ${ }^{28}$ Hvis skyldneren argumenterer for at kassa er tom om seks måneder, eksempelvis gjennom å legge frem et likviditetsbudsjett, vil det i praksis være vanskelig for retten å overprøve dette. Selv om man legger Villars-Dahls forståelse av vilkåret om illikviditet til grunn, synes den praktiske betydningen av rekonstruksjonslovens oppmykning av åpningsvilkåret langt på vei å være begrenset til de tilfellene hvor det fremstår som klart at skyldnerens betalingsevne først vil svikte et stykke frem i tid, eksempelvis to år frem i tid.

\footnotetext{
${ }^{25}$ Prop. 75 L (2019-2020) s. 17, som siterer Utredningen og tilslutning til forslaget fra en rekke høringsinstanser.

${ }^{26}$ Knut Ro og Håvard Wiker, Konkursloven, Oslo 2003, s. 19. Det samme har blitt lagt til grunn for den likelydende formuleringen i kkl. § 61, se Mads Henry Andenæs, Konkurs, 3. utg., Oslo 2009, s. 62-63; Vibeke Irene Løvold, Brcekhus' Omsetning og Kreditt 1: Tvangsfullbyrdelse, gjeldsforhandling og konkurs, Oslo 2015, s. 172-173; og Kåre Lilleholt, «Konsern og konkurs», i Noen sentrale emner innen norsk konkursrett, Oslo 1994, s. 132-133. Se motsatt Kristian Huser, Gjeldsforhandling og konkurs. Bind 2, Bergen 1988, s. 107.

${ }^{27}$ Utredningen s. 33.

${ }^{28}$ Ro og Wiker s. 19.
} 
Det kan spørres om det egentlig er behov for et åpningsvilkår av denne typen. Slik rekonstruksjonslovens regler er utformet, er det jo liten fare for at den kan misbrukes av selskaper til å tvinge igjennom endringer av sine forpliktelser hvor dette er unødvendig for å sikre selskapets solvens. Hvis Utredningens forslag om å forenkle muligheten til å si opp ansatte ved rekonstruksjon hadde blitt vedtatt, ${ }^{29}$ kunne man derimot ha tenkt seg at enkelte selskaper ville ha fors $\varnothing \mathrm{kt}$ å benytte rekonstruksjonsforhandlinger som et middel for å omgå arbeidsmiljølovens regler om oppsigelse. ${ }^{30}$

Fra kreditorhold har det riktignok vært uttrykt bekymring for at rekonstruksjon kan misbrukes til å utsette uunngåelige konkurser, og at rekonstruksjonen dermed spiser opp siste rest av verdier. Faren for dette bør imidlertid anses tilstrekkelig eliminert gjennom tingrettens åpningskjennelse og rekonstruktørens løpende plikt til å vurdere om det er sannsynlig at rekonstruksjonsforhandlingene vil lykkes. ${ }^{31}$ I tillegg vil skyldnerselskapets styre ha en plikt til å vurdere om rekonstruksjon er et realistisk alternativ til konkurs, og brudd på denne plikten vil etter omstendighetene kunne utløse erstatningsansvar etter asl./asal. § 17-1. I alvorlige tilfeller vil det dessuten kunne bli tale om straff etter straffeloven $\S 407 .{ }^{32}$

Også kreditorer kan, som nevnt, begjære åpning av rekonstruksjonsforhandlinger. Terskelen for åpning av slike forhandlinger er ment å være høyere enn der begjæringen kommer fra skyldneren: Kreditors begjæring må påvise at skyldneren er illikvid. Selv om dette vilkåret skulle være oppfylt, kan imidlertid skyldneren sperre for åpning av rekonstruksjonsforhandlinger: Etter lovens $\S 5$ første ledd nr. 4 har skyldneren «vetorett» i den forstand at kreditors begjæring skal avslås hvis skyldneren motsetter seg begjæringen.

\subsection{Kort om prosessen fra åpning av rekonstruksjonsforhandlinger til stadfestelse av en rekonstruksjon med tvangsakkord}

Rettens beslutning om å åpne rekonstruksjonsforhandlinger er startskuddet for en prosess som har til formål å danne grunnlaget for en frivillig rekonstruksjon eller at retten stadfester en tvangsakkord ( $\$ 2$ annet ledd). Retten skal oppnevne en rekonstruktør dersom rekonstruksjonsforhandlinger blir åpnet ( $\$ 8$ første ledd). Vedkommende må være en advokat med erfaring fra insolvensbehandling. Som hovedregel skal retten også oppnevne et kreditorutvalg på

\footnotetext{
${ }^{29}$ Utredningen punkt 14. Se også Prop. 75 L (2019-2020) s. 12.

${ }^{30} \mathrm{Se}$ lov 17. juni 2005 nr. 62 om arbeidsmiljø, arbeidstid og stillingsvern mv. kapittel 15 og 16.

${ }^{31}$ Se rekonstruksjonsloven $\S \S 5,15$ og 25. Sml. også Horst Eidenmueller og Kristin van Zwieten, «Restructuring the European Business Enterprise: the European Commission's Recommendation on a New Approach to Business Failure and Insolvency», European Business Organization Law Review 2015, s. 625-667 (s. 658).

${ }^{32}$ Lov 20. mai 2005 nr. 28 om straff.
} 
ett til tre medlemmer, som i så fall utgjør rekonstruksjonsutvalget sammen med rekonstruktøren. Mandatet til dette utvalget er todelt: Det skal «bistå skyldneren under forhandlingen om rekonstruksjon», men samtidig også «ivareta fordringshavernes felles interesser». I den utstrekning det er forenlig med disse primære pliktene, skal utvalget også ta hensyn til interessene til «berørte arbeidstakere og særlige samfunnsinteresser» ( $\$ 8$ annet ledd). Som hovedregel skal retten i tillegg oppnevne en borevisor til å foreta revisjon av skyldnerens regnskaper og forretningsførsel ( $§ 12)$.

Skyldneren beholder i utgangspunktet rådigheten over virksomheten mens rekonstruksjonsforhandlingene pågår ( $§ 15$ første ledd). Dette betyr at selskapets styre, ledelse og ansatte som hovedregel kan disponere over skyldnerselskapets eiendeler og pådra det forpliktelser i samme utstrekning som forut for forhandlingene. I likhet med gjeldsforhandlinger under konkursloven skiller dermed rekonstruksjonsforhandlinger seg fra konkursbehandling, hvor rådigheten over skyldnerens virksomhet går over til konkursboet. Helt fritt står skyldneren imidlertid ikke. Stiftelse eller refinansiering av gjeld, sikkerhetsstillelse og disposisjoner over eiendeler av vesentlig betydning krever samtykke fra kreditorutvalget ( $\$ 15$ annet ledd). Rekonstruksjonsutvalget fører også generelt tilsyn med skyldnerens økonomiske forhold ( $\$ 15$ første ledd).

En vellykket rekonstruksjon vil, som antydet, resultere i enstemmig godkjennelse av frivillig rekonstruksjon eller at retten stadfester en tvangsakkord. Av plasshensyn begrenser vi oss i det følgende til å se på veien fra åpning av rekonstruksjonsforhandlinger til vedtagelse av tvangsakkord, ettersom dette sporet har størst rettslig og praktisk betydning. Hvis det er enstemmighet om en (frivillig) rekonstruksjon, vil det ofte være like greit å restrukturere skyldneren uten å gå veien om rekonstruksjonsloven.

Skyldneren skal etter at forhandlingene har blitt åpnet, påbegynne arbeidet med et utkast til rekonstruksjon av virksomheten. Rekonstruktøren skal bistå skyldneren i dette arbeidet og gjennomgå skyldnerens virksomhet og kartlegge dennes eiendeler og forpliktelser. Som hovedregel skal det avholdes et fordringshavermøte innen fire uker etter åpningen av forhandlingene. Formålet med møtet er å sondere mulighetene for en løsning som kreditorene kan stille seg bak, og av denne grunn skal skyldneren på møtet legge frem et utkast til rekonstruksjon som fordringshaverne kan uttale seg om. Retten kan beslutte at fordringshavermøte ikke skal avholdes ( $\$ 22)$.

Loven legger opp til at rekonstruksjonsutvalget skal danne seg en oppfatning av om det er utsikt til at skyldneren vil kunne oppnå rekonstruksjon. Selv om loven ikke sier om dette skal skje før eller etter et eventuelt fordringshavermøte, gir det vel best mening å anta at rekonstruksjonsutvalget skal gjøre denne vurderingen etter fordringshavermøtet, hvor kreditore- 
ne har fått anledning til å tilkjennegi sitt foreløpige syn. I praksis vil det gjerne være løpende dialog mellom rekonstruktøren og kreditorene, i hvert fall med de største kreditorene. Det kan her også nevnes at skyldnerens begjæring om åpning av rekonstruksjon skal inneholde «en skisse til hvordan gjelden tenkes ordnet, samt for kontakten med fordringshaverne om dette» (§ 3 annet ledd nr. 3).

Dersom rekonstruksjonsutvalget anser utsiktene for å oppnå en rekonstruksjon som gode, skal utvalget, etter fordringshavermøtet, bistå skyldneren med å utarbeide et endelig forslag til rekonstruksjon. Det endelige forslaget skal så sendes til fordringshaverne for avstemning. Forslaget skal ledsages av en redegjørelse utarbeidet av rekonstruktøren, som blant annet skal inneholde en oversikt over skyldnerens eiendeler og forpliktelser. Dersom det er oppnevnt borevisor, skal revisors innberetning vedlegges redegjørelsen.

Når kreditorene har mottatt forslaget, skal de stemme over dette skriftlig. Rekonstruktøren beslutter avstemningsfristen, som ikke kan være kortere enn to uker ( $\$ 39$ første ledd). Dersom et tilstrekkelig antall kreditorer stemmer for forslaget, skal den vedtatte rekonstruksjonsplanen sendes til retten, som treffer avgjørelsen om hvorvidt rekonstruksjonen skal stadfestes. ${ }^{33}$ Retten skal av eget tiltak kontrollere at lovens vilkår er oppfylt. I tillegg kan retten nekte å godkjenne en vedtatt akkord dersom visse rimelighetskrav ikke er oppfylt. Rettens stadfestelse av en akkord innebærer at den blir bindende for kreditorer som omfattes av akkorden ( $\S$ 54).

\section{$4 \quad$ Finansiering av drift under rekonstruksjonsforhandlingene}

\subsection{Om behovet for likviditet ved rekonstruksjon}

For å kunne finansiere rekonstruksjonsforhandlinger og lykkes med gjennomføringen av en eventuell rekonstruksjon må skyldneren ha tilgang til likviditet. ${ }^{34}$ Men i tillegg til at anstrengt likviditet gjerne vil være en medvirkende årsak til at skyldneren begjærer åpning av rekonstruksjonsforhandlinger, vil likviditeten av flere grunner også kunne bli dårligere når slike forhandlinger igangsettes. Tilgangen på kredittlinjer (som kassekreditt) vil typisk bli blokkert, enkeltkreditorer kan tenkes å intensivere pågangen for å få dekket sine krav, og driftskreditorer som tidligere aksepterte å levere varer og tjenester på kreditt, vil ofte kreve kontant opp-

\footnotetext{
${ }^{33}$ Det følger av rekonstruksjonsloven $\S 42$ at rekonstruksjonen krever tilslutning fra «fordringer som representerer minst en halvdel av det samlede beløp som har stemmerett etter $\S \S 40$ og 41 ». I tillegg gjelder særlige regler etter $\S 34$ tredje ledd ved konvertering av gjeld til egenkapital. Vi kommer tilbake til disse flertallskravene i punkt 6 nedenfor.

${ }^{34}$ Se Utredningen s. 44 flg. For ytterligere innsikt i de praktiske sidene ved likviditetsbehovet, se Aage Figenschou, «Finansiell restrukturering», MarIus nr. 484, 2017.
} 
gjør eller sikkerhet for fortsatt levering. ${ }^{35}$ For å bøte på disse utfordringene inneholder rekonstruksjonsloven flere virkemidler som kan ivareta skyldnerens likviditet.

\subsection{Rekonstruksjonsloven begrenser adgangen til annen kreditorforfølgning}

Rekonstruksjonsloven viderefører i all hovedsak konkurslovens bestemmelser om beskyttelse mot kreditorforfølgning mens gjeldsforhandlinger pågår. For det første kan skyldneren som hovedregel ikke slås konkurs så lenge rekonstruksjonsforhandlingene pågår (§ 17). Dermed kan ikke enkeltkreditorer bruke trusler om konkursbegjæring som et pressmiddel for å få skyldneren til å betale utestående krav. Dette betyr at ledig likviditet i stedet kan brukes til å holde virksomheten i gang. En tilsvarende funksjon har suspensjonen av adgangen til å ta ut$\operatorname{legg}^{36}$ og gjennomføringen av tvangsdekning av panteretter etter tvangsfullbyrdelsesloven kapittel 8 til 12 ( $\$ 18)$. Suspensjonen innebærer at de pantesikrede kreditorer mister et middel for å presse skyldneren til å prioritere å betale den sikrede gjelden. Ledig likviditet kan dermed benyttes til å opprettholde virksomheten i stedet for å betale eksisterende gjeld, så lenge dette skjer åpent og etter styrets (og rekonstruksjonsutvalgets) vurdering av forsvarlighet. Begrensningene i realisasjonsadgangen forhindrer at skyldneren ved tvangsdekning fratas driftskritiske eiendeler, og tilrettelegger dermed også for at skyldneren kan fortsette virksomheten mens rekonstruksjonsforhandlingene pågår.

I tillegg til å $\emptyset$ ke muligheten for at skyldneren selv blir i stand til å drive videre, beskytter disse bestemmelsene også skyldnerens verdier som «going concern»: de gjør det enklere å gjennomføre en rekonstruksjon som innebærer at skyldnerens virksomhet består (enten gjennom nedskrivning av gjeld eller gjennom et samlet salg av virksomheten), fremfor en enkeltvis realisasjon av eiendelene. Man kan derfor begrunne begrensningen på enkeltforfølgning med at eiendelene er mer verdt for skyldneren (den samlede selskapsinteressen) enn det de vil innbringe ved et salg.

\subsection{Rekonstruksjonsloven åpner for lån med "superprioritet»}

Begrensningene i adgangen til enkelt- og fellesforfølgning bidrar til å redusere skyldnerens umiddelbare likviditetsbehov. Loven inneholder også regler som tar sikte på å øke skyldnerens tilgang til likviditet. Kassa vil ofte være bunnskrapt når en skyldner begjærer åpning av rekonstruksjonsforhandlinger, slik at videre drift ikke er mulig med mindre nye midler tilføres. Dersom ikke slike midler bringes til veie, kan skyldneren bli tvunget til å innstille en ellers lønnsom drift, og det er nettopp dette rekonstruksjonsloven tar sikte på å motvirke.

\footnotetext{
${ }^{35}$ Se lov 8. juni 1984 om fordringshavernes dekningsrett (deknl.) § 7-5 som modifisert ved rkl. § 63 tredje ledd.

${ }^{36}$ Se lov 26. juni 1992 nr. 86 om tvangsfullbyrdelse (tvangsfullbyrdelsesloven) kapittel 7.
} 
Et problem mange skyldnere vil støte på, er at alminnelige kilder til likviditet er stengt for selskaper som er i en så prekær situasjon at rekonstruksjonsforhandlinger har blitt åpnet. Investorer vil normalt ikke være villige til å delta i en kontantemisjon før gjeldsproblemene har blitt løst. I tillegg vil långivere vegre seg for å gi usikret kreditt under slike omstendigheter. En mulighet er da å tilby långiverne pantesikkerhet, men dette forutsetter at skyldneren fortsatt har ubeheftede eiendeler som kan stilles som pant. I prosessen frem til åpning av rekonstruksjonsforhandlinger vil imidlertid gjerne de fleste eiendeler allerede være pantsatt. ${ }^{37}$

To nye bestemmelser gjør det likevel mulig for skyldneren å ta opp lån gjennom å tilby såkalt «superprioritet», altså på prioritet foran eksisterende pantesikrede krav for å finansiere videre drift under rekonstruksjonsforhandlingen. Disse bestemmelsene er gitt i rekonstruksjonsloven $\S 19$ og i den nye bestemmelsen i panteloven § 6-5 om legalpant ved rekonstruksjon.

Rekonstruksjonsloven $§ 19$ gir skyldneren adgang til å stifte driftstilbehørs-, varelager- og factoringpant, med prioritet foran eksisterende panthavere. Vilkåret er at pantet tjener til sikkerhet for et lån som går til å finansiere virksomheten og selve rekonstruksjonsforhandlingene. En slik «superprioritet» innebærer et unntak fra prinsippet om tidsprioritet: De nye långiverne vil ved en eventuell senere realisasjon av de pantsatte eiendelene få dekning før långivere med panteretter som skriver seg fra tiden før rekonstruksjonsforhandlingene. Et selskap som er gjenstand for rekonstruksjonsforhandlinger, får dermed adgang til å tilby potensielle långivere sikkerhet på førsteprioritet («superprioritet»), uten å måtte innhente samtykke fra eksisterende panthavere. ${ }^{38}$

Rekonstruksjonsloven $\S 19$ inneholder ikke noen kvantitativ grense for hvor store beløp som kan sikres på førsteprioritet til fortrengsel for eksisterende panthavere. De eksisterende panthaverne har likevel en viss beskyttelse mot at skyldnerens låneopptak urimelig fortrenger deres eksisterende panteretter. For det første er låneopptak med førsteprioritet etter rkl. $§ 19$ betinget av samtykke fra rekonstruksjonsutvalget. Spørsmålet blir dermed hvilke vilkår som gjelder for rekonstruksjonsutvalgets beslutning. Som beslutningsgrunnlag for vurderingen av om samtykke skal gis, skal skyldneren fremlegge et budsjett som viser at det er behov for et slikt lån (§ 19 annet ledd annet punktum). Selv om det ikke fremgår uttrykkelig av lovteksten, må nok dette forstås slik at rekonstruksjonsutvalget bare kan samtykke til nødvendige låne-

\footnotetext{
${ }^{37} \mathrm{Om}$ omfanget av sikret gjeld i selskaper som underlegger seg amerikanske rekonstruksjonsforhandlinger, se Kenneth M. Ayotte, Edith S. Hotchkiss og Karin Thorburn, «Governance in Financial Distress and Bankruptcy», i The Oxford Handbook of Corporate Governance, Oxford 2013, s. 499 med videre henvisninger.

${ }^{38}$ Om avtaler om prioritet, se Kåre Lilleholt, Allmenn formuerett, 2. utg., Oslo 2018, s. 178-180. Se også Thor Falkanger, «Opplåning av pantobligasjoner: ny kreditt sikret ved gamle pantobligasjoner?», Tidsskrift for Rettsvitenskap 1978, s. 35-67, samt NOU 1982: 17 s. 206 flg.
} 
opptak. ${ }^{39}$ Gode grunner taler for at et slikt samtykke også må være betinget av at rekonstruksjonsutvalget, basert på en nøktern og forstandig vurdering, har rimelig grunn til å tro at rekonstruksjonsforhandlingene vil kunne lykkes. Man kan imidlertid ikke kreve at utvalget anser det som sikkert at en løsning vil komme på plass. Det vil gjerne være behov for «superprioritetslån» kort tid etter åpningen av forhandlingene, og beslutningen kan etter omstendighetene måtte treffes før skyldneren har rukket å utarbeide et endelig forslag til rekonstruksjon.

Dersom rekonstruksjonsutvalget samtykker, kan de kreditorene som allerede har pantesikkerhet, begjære at retten omgjør samtykket ( $\$ 19$ annet ledd tredje punktum). Retten kan treffe en slik omgjøringsbeslutning dersom eksisterende panthavers sikkerhet blir «vesentlig forringet», eller retten finner at det ikke er behov for låneopptaket ( 19 annet ledd femte punktum). Vilkåret «vesentlig forringet» viser at det til en viss grad må tolereres at låneopptak på «superprioritet» kan medføre visse tap for eksisterende pantesikrede kreditorer.

Skyldnerens adgang til å tilby pant med «superprioritet» etter rekonstruksjonsloven $§ 19$ gjelder, som nevnt, bare for driftstilbehør-, varelager- og factoringpant. Sammenlignet med hvordan situasjonen var for en skyldner under reglene om gjeldsforhandling etter konkursloven, vil bestemmelsen kunne gjøre det enklere å skaffe ny finansiering for skyldnere med verdier knyttet til varelager, kundefordringer og driftstilbehør.

For skyldnere som hovedsakelig eier andre formuesgoder, som fast eiendom, skip eller luftfartøy, vil derimot bestemmelsen kunne være av mindre nytte. Det er i denne sammenheng av interesse at rekonstruksjonsloven $\S 19$ suppleres av panteloven $\S 6-5$, som ikke er begrenset til visse typer formuesgoder eller -komplekser.

Panteloven § 6-5 første ledd gir lån som er ytt basert på rekonstruksjonsloven $\S 19$, lovbestemt pant over alle formuesgoder som er «beheftet med pant» og «tilhører skyldneren på tidspunktet da rekonstruksjonsforhandlingen blir åpnet», og som «kan være gjenstand for utlegg eller konkursbeslag». ${ }^{40}$ Denne panteretten går foran alle andre heftelser i disse formuesgodene, herunder avtalepant. Til forskjell fra avtalt panterett stiftet i samsvar med kravene i rekonstruksjonsloven $\S 19$ gjelder det imidlertid kvantitative begrensninger for hvor store

\footnotetext{
${ }^{39}$ Slik også Utredningen s. 46 ( «Slik bruk av superprioritet og legalpant bør bare benyttes dersom det ikke finnes andre likvide midler til drift av virksomheten og kostnader til gjeldsforhandlingene.»).

${ }^{40}$ Det er verdt å merke seg forskjellen fra legalpantet etter panteloven $§ 6-4$ første ledd, som også gjelder for «formuesgoder som en tredjeperson har stilt som pantesikkerhet for konkursskyldnerens gjeld». Forskjellen er begrunnet med at departementet, etter innspill fra Finans Norge, fant det uheldig «om realkausjonistens ansvar $\varnothing$ ker som følge av bortfall av skyldnerens pant for å sikre finansiering i rekonstruksjonsperioden», se Prop. 75 L (2019-2020) s. 39.
} 
krav som kan sikres gjennom panteloven $\S$ 6-5. En slik panterett er oppad begrenset til fem prosent av formuesgodets verdi, og når det gjelder realregistrerte formuesgoder - herunder fast eiendom - kan den ikke overstige 700 ganger rettsgebyret. Med et rettsgebyr som p.t. er 1 172 kroner, betyr dette at prioriteten til eksisterende panteretter over hvert enkelt realregistrerte formuesgode kan fortrenges med inntil 820400 kroner.

\subsection{Muligheter og begrensninger}

Sett i europeisk sammenheng, utgjør innføringen i norsk rett av en adgang for skyldneren til å tilby nye långivere pantesikkerhet med prioritet foran eksisterende panteretter en radikal endring. ${ }^{41}$ De nevnte begrensningene betyr imidlertid at ordningen kan være av liten nytte for større selskaper. Den relativt sett begrensede likviditeten som vil kunne tilveiebringes innenfor de kvantitative begrensningene (fem prosent / 700 ganger rettsgebyret), vil ofte være utilstrekkelig til å opprettholde driften av større selskaper. Dette gjelder særlig hvor skyldnerens verdier består av et fåtall verdifulle realregistrerte formuesgoder. For et selskap som eier to næringseiendommer som hver er verdt 80 millioner kroner, kan långiverne maksimalt tilbys «superprioritet» for et beløp lik to ganger 700 ganger rettsgebyret, dvs. totalt 1640800 kroner. Dette utgjør knapt nok én prosent av de underliggende verdiene i dette selskapet.

Disse kvantitative begrensningene kan, når kassa er bunnskrapt, tvinge større virksomheter til raskt å måtte skalere ned, med mindre eksisterende panthavere frivillig går med på å finansiere driften i en periode. En slik forsert nedskalering kan føre til at skyldneren taper markedsandeler. Tap av markedsandeler innebærer at skyldneren blir mindre verdt, noe som igjen kan føre til reduksjon i verdiene til fordeling mellom skyldnerens kreditorer og aksjonærer. Et slikt utfall kan være ekstra uheldig når det kommer i tillegg til den negative utviklingen som har ført til at selskapet har sett seg nødt til å åpne rekonstruksjonsforhandlinger for å overleve.

Adgangen til å ta opp lån med «superprioritet» kan øke skyldnerens tilgang til likviditet samtidig som likviditeten indirekte styrkes av begrensningene etter rkl. $\S 18$ annet ledd av muligheten til å gjennomføre tvangsdekning av pantesikrede krav mens rekonstruksjonsforhandlingene pågår. Denne bestemmelsen begrenser imidlertid bare tvangsdekning som nødvendiggjør namsmyndighetenes medvirkning. ${ }^{42}$ I praksis er det panteretter over fast eiendom og $1 \varnothing$ søre som ikke kan realiseres utenom namsmyndighetene, og som dermed omfattes av begrensningen på enkeltforfølgning etter rkl. § 18 annet ledd.

\footnotetext{
${ }^{41}$ Se European Law Institute, Rescue of Business in Insolvency Law 2017, s. 218.

${ }^{42}$ Se nærmere om dette i tvangsfullbyrdelsesloven $\S 1-3$.
} 
Pant i enkle pengekrav omfattes derimot ikke av begrensningene i rkl. § 18 annet ledd. Siden midler stående på bankkontoer er enkle pengekrav, vil en kreditor med pant i skyldnerens bankkonto kunne ta dekning i slike midler dersom skyldneren misligholder betaling av det sikrede kravet. ${ }^{43}$ Slik avtaler om pant i bankkonto typisk er utformet, vil åpning av rekonstruksjonsforhandlinger være et forhold som gir pantekreditor rett til å instruere kontobanken om ikke å foreta utbetalinger til skyldneren, selv om skyldneren ennå ikke er i betalingsmislighold. Kreditorer med pant i bankkontoer kan dermed strupe skyldnerens tilgang til likviditet dersom skyldneren begjærer rekonstruksjonsforhandlinger.

Begrensningene i skyldnerens adgang til å ta opp lån med «superprioritet», og unntakene fra sperren for tvangsdekning i pantsatte eiendeler, innebærer at den eksisterende ordningen med «superprioritet» ikke trenger å være tilstrekkelig til å holde hjulene i gang mens rekonstruksjonsforhandlinger pågår. Betyr dette at skyldnerens adgang til å ta opp lån med «superprioritet» bør utvides?

Det kan først slås fast at skyldnerens begrensede adgang til å tilby «superprioritet» til fortrengsel for eksisterende panthavere er i tråd med det sterke vernet rekonstruksjonsloven - i likhet med panteloven, dekningsloven og konkursloven - generelt gir sikrede kreditorer. Som vi skal se i punkt 5.2, har dessuten enhver sikret kreditor hvis krav ligger innenfor pantets verdi, i praksis en vetorett overfor rekonstruksjonsforslag som griper inn i dennes rettigheter. Dette gjelder uavhengig av om det godtgjøres at inngrepene ikke har noen negativ innvirkning på de sikrede kreditorenes økonomiske interesser.

Sett fra skyldnerens ståsted kan imidlertid adgangen til å tilby nye långivere pant med «superprioritet» fremstå som vel snever. Hensynet til skyldnerens behov for rekonstruksjon må imidlertid avstemmes med hensynet til de kreditorene som har ytt kreditt basert på pantesikkerheten. En vid adgang for skyldneren til å tilby «superprioritet» vil gjøre det mer risikabelt å yte sikrede lån til selskaper; man vil ikke på samme måte kunne stole på sikkerheten. Dette kan igjen bety høyere rentemarginer og dårligere tilgang til lån for en del selskaper, og i visse tilfeller kan risikoen for å bli fortrengt av etterfølgende lån på «superprioritet» være forskjellen på om et selskap får lån eller ikke. Det er nettopp slike argumenter som gang på gang har begrunnet en utvikling som - med få unntak - har gått i retning av å utvide adgangen til pantset-

\footnotetext{
${ }^{43}$ Om klassifisering av pant i innskudd på konto, se Thor Falkanger, «Sikkerhet i egen forpliktelse», Lov og Rett 2020, s. 325-337 (s. 326 flg.).
} 
telse av stadig flere eiendeler og beskytte pantesikrede kreditorers særrett til dekning foran usikrede kreditorer, både i Norge og i en rekke andre sammenlignbare land. ${ }^{44}$

I hvilken grad det bør være adgang til å belåne skyldnerens pantsatte eiendeler med «superprioritet», må bero på en avveining mellom hensynet til å sikre selskaper tilgang til kreditt og hensynet til å sikre kriserammede selskaper likviditet. Det er vanskelig å fastslå i hvilken grad innhugg i prioriteten til sikrede kreditorer reduserer tilgangen på lån. Sjelden har det kommet mer ærlig til uttrykk enn da Justisdepartementet vurderte Falkanger-utvalgets forslag om å oppheve adgangen til å stille factoring- og varelagerpant. I begrunnelsen for hvorfor ikke dette forslaget ble tatt med $\mathrm{i}$ den etterfølgende lovproposisjonen, opplyste departementet at det $\mathrm{i}$ samråd med Finansdepartementet og Nærings- og handelsdepartementet forsøkte å konkretisere virkningene for kredittilførselen, men hadde «måttet resignere på dette punktet». ${ }^{45}$

Det fremstår imidlertid intuitivt riktig at jo mer absolutt den sikrede kreditorens rett til fortrinnsvis dekning i det pantsatte formuesgodet er, desto mer villig vil denne være til å yte lån, noe Justisdepartementet også la til grunn. ${ }^{46}$ Vi skal ikke her forsøke å gi noe bidrag til diskusjonen om hvor absolutt vernet av sikrede kreditorer bør være. Poenget er kun å påpeke at hensynet til å sikre selskaper i rekonstruksjonsforhandlinger tilgang til likviditet gjennom adgang til å ta opp «superprioritetslån», står i spenning til hensynene som begrunner det sterke vernet av pantesikrede kreditorer i norsk rett.

\section{$5 \quad$ Rekonstruksjonens innhold}

\subsection{Hva slags inngrep kan en rekonstruksjon bestå i?}

I det følgende skal vi se nærmere på de materielle grensene for hva en rekonstruksjon kan gå ut på. Dette er med andre ord både et spørsmål om hva slags endringer en rekonstruksjon kan hjemle, noe vi omtaler i dette avsnittet, og et spørsmål om hvilke fordringer som overhodet kan bli gjenstand slike endringer (punkt 5.2). De prosessuelle kravene, herunder kravene til samtykke fra kreditorer og aksjonærer, behandles i punkt 6 .

Loven oppstiller, som nevnt ovenfor i punkt 3.2, to spor for vedtakelse av en rekonstruksjon. Det første sporet er frivillig rekonstruksjon. Som ordet «frivillig» impliserer, forutsetter ved-

\footnotetext{
${ }^{44}$ Se Sjur Swensen Ellingsæter, Creditor Priority and Financial Stability: A study of the emergence and rationales of the creditor hierarchy in EU and EEA bank insolvency law, Doktoravhandlinger forsvart ved Det juridiske fakultet, Universitetet i Oslo nr. 148, Oslo 2020, s. 156-157.

${ }^{45}$ Ot.prp. nr. 26 (1998-1999) s. 168.

${ }^{46}$ I samme retning den svenske regjeringens Prop. 2007/08:161 (Företagshypotek - en bättre säkerhet för lån till företag), særlig s. 39 flg., og John Armour mfl., «How do creditor rights matter for debt finance? A review of empirical evidence», i Research Handbook on Secured Financing in Commercial Transactions, Cheltenham 2015.
} 
tagelse her samtykke fra samtlige berørte parter. Rekonstruksjonsloven $\S 27$ første ledd gir eksempler på hvilke endringer en frivillig rekonstruksjon kan gjøre i skyldnerens gjeldsforpliktelser. Denne listen er imidlertid ikke uttømmende. I prinsippet er det derfor bare fantasien som setter grenser for hvilke endringer en frivillig rekonstruksjon kan gjøre i kravene til samtykkende kreditorer (og aksjonærer).

Lovens andre spor er rekonstruksjon ved tvangsakkord. Som vi kommer tilbake til, er det her tale om en ordning hvor et flertall av berørte kreditorer kan vedta endringer foreslått av skyldneren. Sagt med andre ord: Et flertall kan påtvinge mindretallet en løsning. Siden en slik ordning vil gripe inn i rettighetene til enkelte kreditorer mot deres vilje, angir rkl. § 34 første ledd en uttømmende liste over hva slags inngrep som kan gjennomføres med rekonstruksjon ved tvangsakkord. ${ }^{47}$ Dette er følgende inngrep:

- Betalingsutsettelse.

- Prosentvis reduksjon av gjelden.

- Omgjøring av hele eller deler av gjelden til egenkapital.

- Overdragelse av hele eller deler av skyldnerens virksomhet og eiendeler til ny eier, uten at skyldnerens virksomhet blir likvidert.

- Overdragelse og avvikling av hele eller deler av skyldnerens virksomhet og eiendeler mot at skyldneren blir frigjort for den delen av gjelden som ikke dekkes ved likvidasjonen.

- En kombinasjon av disse ordningene.

De tre første punktene på listen innebærer at en tvangsakkord kan gå ut på å endre de to essensielle elementene $i$ et pengekrav: når kravet skal betales, og hvor mye som da skal betales.

En betalingsutsettelse kan i noen tilfeller være tilstrekkelig til å få en kriserammet skyldner «over kneika». Det forekommer at en skyldner ikke har tilstrekkelig inntjening til å betjene gjelden sin i dag, men likevel forventer å kunne gjøre det i fremtiden når inntjeningen bedres. Gjennom en betalingsutsettelse beholder kreditorene hver krone av kravene sine. Ulempen består i å få betaling senere enn opprinnelig avtalt. Dessuten er det alltid en risiko for at inntjeningen forverres, i strid med skyldnerens prognoser.

Andre skyldnere vil derimot ha mer permanente betalingsproblemer. For slike skyldnere gir ikke en betalingsutsettelse alene noen fullgod løsning; når det utskutte forfallstidspunktet kommer, vil de fremdeles ikke være i stand til å betale. I slike tilfeller kan det være nødvendig

\footnotetext{
${ }^{47}$ Prop. 75 L (2019-2020) s. 71.
} 
med sterkere lut: Betalingsforpliktelsene må reduseres permanent. Selv om rekonstruksjonsloven åpner for at en tvangsakkord kan gå ut på å skrive ned gjelden til skyldneren, er det ikke gitt at et forslag om en slik løsning oppnår tilstrekkelig støtte blant kreditorene, i og med at de derved gir avkall på deler av kravene sine for evig tid. Det vil ikke da nødvendigvis være slik at konkurs anses som et verre alternativ for kreditorene. Det hele avhenger av om nåverdien av fordringene de berørte kreditorer sitter igjen med etter tvangsakkorden, overstiger nåverdien av dividendebetalingene de vil motta i en eventuell konkurs.

Adgangen til å vedta en tvangsakkord som omgjør gjeld til egenkapital, er en nyvinning i rekonstruksjonsloven som gjør det mulig å $\varnothing \mathrm{ke}$ (de potensielle) verdiene kreditorene sitter igjen med ved en tvangsakkord. En slik omgjøring av kreditorkrav til aksjer vil kunne gjøre akkorden mer attraktiv for kreditorene enn en akkord som går ut på en ren nedsettelse av kravene. Ved at kreditorene mottar aksjer som kompensasjon for å godta å gi avkall på hele eller deler av kravene, omgjøres - eller for å bruke et uttrykk som er vanlig i praksis, konverteres - gjelden til aksjer. Dersom skyldnerens virksomhet kommer på fote igjen, kan kreditorene potensielt innkassere en gevinst - i form av utbyttebetalinger og/eller vederlag for salg av aksjene som overstiger kravene de gjennom rekonstruksjonen gir avkall på.

Etter aksjeloven $\S 10-2$ skjer en slik konvertering ved at fordringen på skyldneren motregnes mot plikten til å betale for aksjene. Det må fremgå uttrykkelig av generalforsamlingsbeslutningen at aksjeinnskuddet skal kunne gjøres opp ved motregning. Det alminnelige forbudet i aksjeloven § 2-12 første ledd mot å tegne aksjer til underkurs antas ikke å gjelde for oppgjør ved slik motregning, noe som betyr at fordringens pålydende kan brukes som betaling selv om skyldnerens betalingsevne er så svekket at fordringens verdi er antatt å være lavere enn pålydende. ${ }^{48}$ Det at rekonstruksjonsloven eksplisitt tillater slik konvertering, gjør nok at antakelsen i forarbeidene til aksjeloven blir enda sikrere («etterarbeid»). Samtidig er det viktig å påpeke at departementet var opptatt av at konvertering av gjeld til aksjer som ledd i en rekonstruksjon måtte følge aksjelovens alminnelig regler på vanlig måte. $^{49}$

Det fjerde og femte punktet i rekonstruksjonsloven $\S 34$ første ledd hjemler overdragelse av «skyldnerens virksomhet og eiendeler». Mens det er klart hva det vil si å overdra eiendeler, er det mindre klart hva det her vil si å overdra skyldnerens virksomhet. I tillegg til eiendeler vil en virksomhet gjerne bestå av uoppfylte avtaler. Overdragelse av slike avtaler forutsetter medkontrahentens samtykke, og det er ikke noe i rekonstruksjonsloven som endrer på dette utgangspunktet. Det er usikkert om $§ 34$ første ledd også hjemler overdragelser som omfatter deler av skyldnerens gjeld. Det kan hevdes at gjeldsposter ikke utgjør en del av selve virk-

\footnotetext{
${ }^{48}$ Magnus Aarbakke mfl., Aksjeloven, kommentarutgave, Lovkommentar på Juridika.no (ajourført per 1. juli 2019), kommentar til aksjeloven $\S 10-2$ med videre henvisninger til Ot.prp. nr. 19 (1974-75) s. 57.

${ }^{49}$ Prop. 75 L (2019-2020) s. 50.
} 
somheten, men lovgivningen inneholder eksempler på at man med «overdragelse av virksomhet» også sikter til forpliktelser. ${ }^{50}$

\subsection{Hvilke fordringer kan omfattes av en rekonstruksjon med tvangsakkord?}

Etter rkl. $§ 54$ første ledd skal som hovedregel en tvangsakkord omfatte «alle [...] fordringer som skriver seg fra tiden før åpningen av rekonstruksjonsforhandlingen». Det gjelder imidlertid unntak fra dette utgangspunktet. Sikrede, fortrinns- og motregningsberettigede kreditorer er unntatt som sådanne fra reglene om tvangsakkord. Dette betyr blant annet at en skyldner ikke kan få stadfestet en tvangsakkord som går ut på å konvertere eller redusere kravene til slike kreditorer. Det må derimot være adgang for slike kreditorer til frivillig å gå med på konvertering eller andre endringer av kravene deres.

Det vil imidlertid ikke være mulig å ha to parallelle lovregulerte rekonstruksjonsforhandlinger pågående på samme tid. Skyldneren kan altså ikke kombinere bruken av frivillig rekonstruksjon med en tvangsakkord for enkelte av kreditorene; her må skyldneren velge den prosessen som er best egnet til å oppnå rekonstruksjon. Dette er imidlertid ikke til hinder for å kombinere en tvangsakkord med frivillige avtaler, eksempelvis å inngå private avtaler med de kreditorene som ikke kan bindes av tvangsakkorden, eller å inngå slike avtaler med kreditorer som har akseptert å stå tilbake for de øvrige kreditorene. Tvangsakkorden kan trolig inneholde en betingelse om at slike private avtaler må ha trådt i kraft for at tvangsakkordens endringer skal bli virksomme. Retten kan gi rekonstruktøren eller en annen person oppgaven med å kontrollere at betingelsene har inntrådt ( $§ 50)$.

Et sikret krav anses bare som sikret - og dermed beskyttet mot tvangsakkord - dersom verdien av panteobjektet er likt eller høyere enn pantekravet ( $\$ 36$ første ledd). Hvis et pantesikret krav er på 2000000 kroner, men panteobjektet kun er verdt 1200000 kroner, regnes kun 1200000 kroner som sikret, og de overskytende 800000 kroner kan altså omfattes av tvangsakkorden. Verdsettelsen av panteobjektet ligger til rekonstruksjonsutvalget ( $\$ 36$ annet ledd). Hvis rekonstruksjonsutvalgets vurdering er at et pantesikret krav skal anses som (delvis) usikret, kan panthaveren bringe verdsettelsen inn for retten. Derimot kan tilsynelatende ikke skyldneren eller de øvrige fordringshaverne klage dersom rekonstruksjonsutvalget kommer til motsatt konklusjon. Loven er dermed til en viss grad vridd mot å anerkjenne pantesikrede krav som fullt ut sikrede, hvilket er til de sikrede kreditorenes gunst.

\footnotetext{
${ }^{50}$ Se henvisningen i asl. § 9-6 første ledd til overdragelse av virksomhet ved fusjon og fisjon. Per definisjonene i hhv. asl. §§ 13-2 første ledd og 14-2 første ledd kan fusjon og fisjon omfatte overdragelse av forpliktelser.
} 
Fortrinnsberettigede krav omfatter kravene som er fortrinnsberettigede til dividende i konkurs. Dette gjelder for det første kravene som er angitt i deknl. § 9-3, kort sagt lønnskrav som har forfalt relativt kort tid forut for konkursen (her: rekonstruksjonen). For det andre nyter enkelte skatte- og avgiftskrav fortrinnsrett bak de nevnte lønnskravene, men foran $\emptyset$ vrige usikrede krav, jf. deknl. § 9-4. I henhold til en nylig vedtatt forskrift skal imidlertid flere av de nevnte skatte- og avgiftskravene ikke regnes som fortrinnsberettigede ved anvendelsen av rekonstruksjonsloven $\S 54 .{ }^{51}$ De aktuelle skatte- og avgiftskravene kan dermed omfattes av en tvangsakkord etter rekonstruksjonsloven.

Selskaper vil ofte ha løpende gjensidig bebyrdende avtaler, eksempelvis strømavtaler, avtaler om leie eller leasing av forskjellig løsøre og avtaler om leie av lokaler. I tillegg vil de fleste selskaper ha en eller flere ansatte. Felles for slike løpende avtaler er at både skyldneren og avtalemotparten har utestående forpliktelser. Hovedregelen, som fremgår av deknl. § 7-3 a, er at alle gjensidig bebyrdende avtaler løper videre uavhengig av om det åpnes rekonstruksjonsforhandlinger. ${ }^{52}$ Enkelte særregler kan imidlertid modifisere dette utgangspunktet. Skyldnerens motpart kan kreve sikkerhet for skyldnerens oppfyllelse uavhengig av om en slik rett følger av avtalen, ${ }^{53}$ mens skyldneren «uansett avtalens bestemmelser om oppsigelse, [kan] si opp avtalen med sedvanemessig varsel, eller dersom slik sedvane ikke foreligger, med tre måneders varsel». 54

Sett fra skyldnerens ståsted vil det kunne være ønskelig å gjøre avtalevilkårene mer gunstige. Dermed oppstår spørsmålet om en uoppfylt avtale kan endres som ledd i en tvangsakkord. Kan f.eks. en tvangsakkord inneholde et vilkår om å halvere det beløpet skyldneren plikter å betale for leie av forretningslokaler? Dette gir opphav til to beslektede spørsmål. For det første: Kan en tvangsakkord endre på kontraktsmotpartens rett til å motta vederlaget som er avtalt for hans motytelse? For det andre: Kan en tvangsakkord medføre at kontraktsmotparten blir forpliktet til å prestere sin ytelse for et lavere vederlag enn opprinnelig avtalt?

Av rkl. § 54 jf. deknl. § 6-1 fremgår det at det er fordringer mot skyldneren som er gjenstand for endring ved tvangsakkord. Motpartens rett på vederlag fra skyldneren er en fordring. At fordringen er betinget av at motparten presterer sin ytelse, er i denne sammenheng irrelevant $\mathrm{i}$ og med at $§ 54$ jf. deknl. § 6-2 også omfatter betingede krav. Dette betyr at svaret på det første

\footnotetext{
${ }^{51}$ Forskrift 11. mai $2020 \mathrm{nr} .974$ om midlertidig unntak fra prioritetsreglene under rekonstruksjon etter midlertidig lov om rekonstruksjon for å avhjelpe økonomiske problemer som følge av utbrudd av covid-19.

${ }^{52}$ Sml. deknl. § 7-3 som gir konkursboet rett, men ikke plikt til å tre inn i konkursskyldnerens uoppfylte kontrakter.

${ }^{53}$ Deknl. § 7-5 som endret ved rkl. § 63 tredje ledd.

${ }^{54}$ Deknl. § 7-6 første ledd første punktum.
} 
spørsmålet er ja: En tvangsakkord kan gå ut på å redusere det vederlaget motparten har rett til å motta fra skyldneren mot å prestere sin ytelse. Dette innebærer i prinsippet blant annet at utleierens rett til leiebetalinger kan reduseres. Rekonstruksjonsloven inneholder derimot ingen bestemmelser som hjemler endringer av motpartenes plikter overfor skyldneren. Motparten er dermed ikke forpliktet til å prestere sin ytelse for et lavere vederlag enn avtalt. Dette betyr at en tvangsakkord eksempelvis ikke kan forplikte en utleier til å stille lokaler til disposisjon for skyldneren mot halvparten av leien partene i sin tid ble enige om.

I tråd med dette har de tilsvarende bestemmelsene om gjeldsforhandling i konkursloven blitt forstått slik at en tvangsakkord kan endre løpende avtaler, men at motparten kan heve avtalen og kreve erstatning for resulterende tap i medhold av henholdsvis deknl. §§ 7-7 første ledd annet punktum og 7-8. ${ }^{55}$ Dette betyr at endring av avtalen krever kontraktsmotpartens samtykke. Det samme følger forutsetningsvis av deknl. § 7-4 a første ledd annet punktum. Selv om et eventuelt erstatningskrav oppstår som en følge av begivenheter som inntreffer etter åpningen av rekonstruksjonsforhandlingen, regnes erstatningskravet for å ha oppstått før gjeldsforhandlingen ved anvendelsen av kkl. $§ 55$, som tilsvarer rkl. $§ 54 .{ }^{56}$ Dette betyr igjen at erstatningskravet kan gjøres til gjenstand for en tvangsakkord. Løsningen må nok bli den samme etter rekonstruksjonsloven.

Skyldneren kan dermed i praksis velge mellom å fastholde avtalen på gjeldende vilkår, å benytte den ekstraordinære oppsigelsesadgangen i deknl. § 7-6, eller å fremprovosere en heving og et erstatningsansvar som skyldneren delvis kan «kvitte seg med» gjennom en tvangsakkord. Skyldneren kan derimot ikke benytte en tvangsakkord til å binde motparten til vilkår som er mer fordelaktige for skyldneren. Riktignok kan skyldneren utforme forslaget til tvangsakkord slik at vederlaget skyldneren skal betale også for fremtidige ytelser, skal reduseres, men dette vil altså ikke binde en motvillig kontraktsmotpart; det vil trolig føre til at han hever. ${ }^{57}$ Særlig for avtaler om leie av lokaler vil det være lite fristende for skyldneren å forfølge dette sporet. Heving av leieavtalen vil resultere i at skyldneren må fravike lokalene, og tilgang til forretningslokalene er som oftest en grunnleggende forutsetning for videre drift. Dette betyr at de fleste skyldnere i praksis ikke har annet valg enn å fastholde avtaler hvor motpartens ytelse er kritisk for videre drift, selv om vederlaget i avtalen på tidspunktet for rekonstruksjonen er høyere enn markedsprisen for tilsvarende ytelser.

Skyldnerens låneavtaler kan inneholde forpliktelser utover plikten til å betale renter og hovedstol. For eksempel er det ikke sjelden at bank- og obligasjonslåneavtaler inneholder krav om

\footnotetext{
${ }^{55}$ NOU 1993: 16 s. 116.

${ }^{56}$ NOU 1993: 16 s. 116.

${ }^{57}$ NOU 1993: 16 s. 116.
} 
at låntakeren må tilfredsstille visse finansielle målkrav, som høyeste tillatte gjeldsgrad eller minstekrav til beholdning av likvide midler. ${ }^{58}$ Brudd på slike forpliktelser vil - eventuelt etter utløpet av en rettefrist - utgjøre et mislighold som gir långiver rett til å kreve førtidig innfrielse av lånet. En skyldner som søker tvangsakkord, vil ha interesse av å endre slike avtalebestemmelser, i og med at resultatet ellers kan bli at skyldneren umiddelbart etter avslutningen av rekonstruksjonsforhandlingene kommer i brudd med vilkårene i slike låneavtaler.

Kan finansielle målkrav og lignende avtalebestemmelser endres gjennom en tvangsakkord? Slike endringer er ikke uttrykkelig nevnt i den uttømmende listen av inngrep som en tvangsakkord etter rkl. $\S 34$ kan bestå i. Det kan imidlertid hevdes at endringer av slike avtalebestemmelser må likestilles med en form for betalingsutsettelse som kan vedtas etter rkl. § 34 første ledd nr. 1. En av sanksjonene for mislighold av finansielle målkrav o.l. er nemlig at långiver kan kreve førtidig tilbakebetaling av lånet. Når låntakeren har misligholdt låneavtalen, kan man dermed se det slik at långivers rett til betaling i henhold til avtalt betalingsplan suppleres av en rett til betaling ved påkrav. Dersom avtalen endres slik at de aktuelle omstendighetene (brudd på finansielle målkrav osv.) ikke lenger utgjør mislighold, vil dette også innebære at långiveren mister retten til å kreve tilbakebetaling ved påkrav, og igjen kun kan kreve betaling som angitt $\mathrm{i}$ betalingsplanen.

Basert på et slikt synspunkt kan man se det slik at en endring av låneavtalens bestemmelser om finansielle målkrav o.l. utgjør en betalingsutsettelse. Løsningen er her uklar. I og med at en normal språklig forståelse av ordet «betalingsutsettelse» neppe omfatter endringer av bestemmelser som er av mer indirekte betydning for låntakers betalingsforpliktelser, og at lovgivers forutsetning er at $\S 34$ positivt skal angi alle tiltak som kan gjennomføres gjennom tvangsakkord, heller vi mot at endringer av finansielle målkrav o.l. ikke omfattes av $\S 34$. Dermed kan ikke slike endringer gjennomføres som ledd i en tvangsakkord.

\section{$6 \quad$ Flertallskrav og minoritetsvern}

\subsection{Det generelle flertallskravet}

Rekonstruksjon ved tvangsakkord skiller seg fra det alminnelige utgangspunktet om at endring av en betalingsforpliktelse forutsetter samtykke fra kreditor. Hvis målet var å få i stand flest mulig rekonstruksjoner, ville et effektivt virkemiddel være å fravike kravet til kreditorsamtykke, som ved tvungen gjeldsordning for privatpersoner. ${ }^{59}$ Rekonstruksjonsloven går

\footnotetext{
${ }^{58}$ Edward I. Altman, Edith Hotchkiss og Wei Wang, Corporate Financial Distress, Restructuring and Bankruptcy, 4. utg., Hoboken, New Jersey 2019, s. 29.

${ }^{59}$ Se gol. kapittel 5 .
} 
imidlertid ikke så langt. Løsningen er i stedet at et flertall av kreditorene som berøres av forslaget, kan binde både seg selv og øvrige berørte kreditorer til å akseptere tvangsakkorden.

Flertallskravet i rekonstruksjonsloven er redusert sammenlignet med flertallskravet etter konkursloven: Det kreves at kreditorer som representerer minst en halvdel av det samlede beløpet av fordringer med stemmerett, stemmer for forslaget $(\S 42) .{ }^{60}$ Flertallskravet er altså et krav til flertall blant samtlige stemmeberettigede kreditorer, og flertallskravet knytter seg dermed ikke til de kreditorene som faktisk stemmer over forslaget.

Et sentralt spørsmål er dermed hvilke fordringer som gir stemmerett. Det følger av rkl. § 41 at alle kjente fordringer som hovedregel skal ha stemmerett. Det gjelder imidlertid praktisk viktige unntak fra dette utgangspunktet. En første gruppe unntak tar sikte på ikke å gi stemmerett til kreditorer som ikke har noen interesse av utfallet av avstemningen. Fordringer som etter $\S 54$ ikke kan bindes av en tvangsakkord - dvs. sikrede, fortrinns- og motregningsberettigede kreditorer - får av denne grunn ikke stemmerett ( $\$ 41$ første ledd nr. 1). Det samme gjelder kreditorer hvis rettigheter ikke berøres av forslaget ( $\$ 41$ første ledd nr. 5). Stemmerett tilkommer heller ikke kreditorer med betingede krav ( 41 første ledd nr. 2), herunder kreditorer under garantier stilt av skyldneren, så fremt garantiansvaret ikke har blitt utløst. Videre gjelder det unntak for krav som tilhører skyldnerens nærstående ( $\$ 41$ første ledd nr. 4), krav som har blitt ervervet etter åpningen av rekonstruksjonsforhandlingene ( $\$ 41$ første ledd nr. 3), og fordringer som er etterstilte i konkurs i henhold til deknl. § 9-7 i den utstrekning de skal falle bort ved tvangsakkorden ( $\$ 41$ første ledd nr. 6).

\subsection{Vilkårene for vedtagelse av en gjeldskonvertering}

Som vist ovenfor i punkt 5.1 kan et tilbud om bytte av gjeld mot aksjer være forskjellen mellom et vedtatt og et avslått forslag om tvangsakkord. Konvertering av gjeld til aksjer reiser imidlertid flere problemstillinger de lege ferenda.

En sentral problemstilling knytter seg til i hvilken grad kreditorer bør kunne tvinges til å ta del i en gjeldskonvertering og dermed bli aksjonærer i skyldneren. Kreditorer er en heterogen gruppe. Rettsgrunnlaget for kravene deres kan være alt fra låneavtaler til offentligrettslige regler, og det vil dermed variere om kreditorposisjonen skyldes et bevisst valg om å eksponere seg mot skyldnerens økonomiske utvikling. Det vil også kunne variere hvor egnet kredito-

\footnotetext{
${ }^{60}$ Etter konkursloven $\S 43$ er regelen at en tvangsakkord kan vedtas så fremt 3/5 (ved akkord på over $50 \%$ ) eller $3 / 4$ (ved akkord under $50 \%$ ) av de stemmeberettigede fordringshaverne har samtykket. Etter konkursloven $\S$ 43 første og annet ledd kreves det i tillegg at de nevnte flertallskravene er oppfylt når en ser på antallet fordringshavere som har deltatt i avstemmingen. Dette tilleggskravet ble ikke videreført i rekonstruksjonsloven.
} 
rer er til å sitte med langvarige aksjeinvesteringer i unoterte aksjeselskaper, noe som kan bli resultatet av en gjeldskonvertering. De videre konsekvensene for kreditorene av en slik konvertering vil også kunne variere. Vi nøyer oss her med å peke på to forhold. For det første oppstiller regnskapsreglene som gjelder for banker, ulike prinsipper for regnskapsføringen av henholdsvis fordringer og aksjer. Dette kan igjen få betydning for oppfyllelse av kapitaldekningsreglene som gjelder for banker. ${ }^{61}$ For det andre begrenser finansforetaksloven bankers adgang til å eie aksjer som gir bestemmende innflytelse over selskaper som hverken driver med virksomhet banker har tillatelse til å drive eller virksomhet som har naturlig tilknytning til denne. ${ }^{62}$

Rekonstruksjonslovens løsning på dette er hovedregelen i § 34 tredje ledd om at konvertering av gjeld til aksjer «bare [kan] omfatte fordringshavere som samtykker til dette». Unntaksvis kan retten beslutte at ordningen skal omfatte samtlige fordringshavere dersom de av fordringshaverne som ikke samtykket, «åpenbart ikke har rimelig grunn til dette».

Dette reiser spørsmålet om hva det vil si at «[e]n ordning med omgjøring av gjeld til egenkapital [...] bare [kan] omfatte fordringshavere som samtykker til dette». Etter ordlyden må det nok være klart at et forslag som går ut på å konvertere all berørt gjeld til aksjer, krever samtykke fra samtlige berørte kreditorer. Men innebærer bestemmelsen også et krav om samtykke fra samtlige kreditorer dersom de alle får skrevet ned kravene sine, men kun de som vil, får aksjer i bytte? Hvis dette er tilfellet, har hver enkelt kreditor i praksis en vetorett når rekonstruksjonen innebærer konvertering av gjeld til aksjer. I og med at et flertall gjerne ikke vil støtte en nedskrivning av gjeld med mindre aksjer utstedes som vederlag for gjeldsavkortningen, betyr en slik vetorett at enkeltkreditorer i praksis vil kunne stanse ethvert fors $\emptyset$ kå å vedta en tvangsakkord som reduserer skyldnerens gjeldsforpliktelser. Vårt syn er at det må være adgang til å få stadfestet en tvangsakkord hvor mottak av aksjer er frivillig. Lovens ordlyd stenger ikke for en slik løsning. Videre begrunner forarbeidene regelen i § 34 tredje ledd første punktum med at «det kan virke urimelig å påtvinge kreditorer aksjer i stedet for dividende når de ikke ønsker dette». ${ }^{63}$ Når kreditorene beholder deler av fordringene sine og står fritt til å velge om de i tillegg vil motta aksjer, blir ingen kreditor «påtvunget» aksjer. Forarbeidenes begrunnelse gjør seg da ikke gjeldende. Som vi kommer tilbake til i punkt 6.3, er imidlertid $\S 48$ første ledd nr. 1 til hinder for en slik løsning dersom utfallet blir at de som

\footnotetext{
${ }^{61}$ Se Europaparlaments- og rådsforordning (EU) nr. 575/2013 om tilsynskrav for kreditt- og verdipapirforetak, som er inkorporert i norsk rett gjennom $\S 2$ i forskrift 22. august 2014 nr. 1097 om kapitalkrav og nasjonal tilpasning av CRR/CRD IV.

${ }^{62}$ Se lov 10. april 2015 nr. 17 om finansforetak og finanskonsern $§ 13-1$ og unntakene i $\S 13-2$ annet ledd, som blant annet gjelder for midlertidig eierskap av andeler i slik bankfremmed virksomhet som er «n $\varnothing$ dvendig som ledd i en økonomisk sanerings- eller redningsaksjon».

${ }^{63}$ Prop. 75 L (2019-2020) s. 50.
} 
velger å motta aksjer, sitter igjen med urimelig høye verdier sammenlignet med de som velger å avstå.

Skyldnerens aksjonærer må samtykke til en gjeldskonvertering. Utstedelse av nye aksjer forutsetter vedtektsendring, og en utenrettslig gjeldskonvertering må derfor godkjennes på generalforsamling av «minst to tredeler så vel av de avgitte stemmer som av den aksjekapital som er representert på generalforsamlingen». ${ }^{64}$ Det samme flertallskravet gjelder dersom eksisterende aksjonærers fortrinnsrett til å tegne nye aksjer skal fravikes, ${ }^{65}$ noe en gjeldskonvertering nødvendigvis må gjøre. Rekonstruksjonsloven firer på disse kravene når utstedelsen av aksjer skjer som ledd i en frivillig rekonstruksjon eller en tvangsakkord. Da er det tilstrekkelig med tilslutning fra «minst halvparten så vel av de avgitte stemmer som av den aksjekapitalen som er representert på generalforsamlingen» (§§ 27 annet ledd og 35 første ledd).

\subsection{Vern av konkursprioritet}

Både konkurs og rekonstruksjon som går ut på nedskrivning av gjeld, fremtvinger en tapsfordeling blant kreditorene, i og med at følgen i begge tilfeller blir at noen kreditorer ikke vil få det de har krav på fra skyldneren. I konkurs gjør spørsmålet om tapsfordeling seg gjeldende som et spørsmål om utdeling av knappe midler. Reglene for hvordan skyldnerens midler skal fordeles, er klare. De alminnelige usikrede kreditorene får kun dekket sine krav i den utstrekning noe gjenstår av skyldnerens midler etter dekning av krav med særskilt dekningsrett, omkostningene ved bobehandlingen og kravene til fortrinnsberettigede kreditorer. I den grad de resterende midlene kun delvis dekker summen av kravene til de alminnelige usikrede kreditorene, skal midlene fordeles proratarisk.

Ved en rekonstruksjon som går ut på nedskrivning av gjeld, gjør spørsmålet om tapsfordeling seg gjeldende på en noe annen måte. Her er det ikke tale om å utdele knappe midler. En slik rekonstruksjon dreier seg snarere om hvordan man skal fordele den byrden det innebærer å ikke motta full betaling fra en skyldner som skal fortsette med videre drift, slik at uberørte kreditorer formodentlig mottar full betaling av kravene sine. Likevel gjelder både dette spørsmålet og spørsmålet om fordelingen av skyldnerens midler i konkurs grunnleggende sett plassering av de tapene som med nødvendighet må bæres av noen kreditorer når skyldnerens betalingsevne svikter.

Det fremstår intuitivt som nærliggende at byrdefordelingen ved en nedskrivning ved rekonstruksjon bør speile det som gjelder ved fordelingen av skyldnerens midler i en konkurs, dvs.

\footnotetext{
${ }^{64}$ Se asl./asal. § 5-18 første ledd. Strengere flertallskrav kan følge av vedtektene, $§ 5-18$ tredje ledd.

${ }^{65} \mathrm{Se}$ asl./asal. $\S 10-5$.
} 
prioritetsreglene i dekningsloven kapittel $9 .{ }^{66}$ For de alminnelige usikrede kreditorene skulle dette bety at en rekonstruksjon enten omfatter dem alle eller at ingen alminnelige usikrede krav skrives ned. Og hvis en nedskriving eller konvertering skal speile reglene om konkursprioritet, vil dessuten samtlige alminnelige usikrede kreditorer måtte tåle den samme prosentvise nedskrivningen. Et slikt krav gjenfinner man imidlertid hverken i konkurslovens regler om gjeldsforhandling eller i rekonstruksjonsloven. Tvert imot angir lovene at en tvangsakkord kan gå ut på at alle krav skal dekkes opp til en viss sum, noe som innebærer at det vil være mulig å skyve den relative byrden over på større kreditorer. ${ }^{67}$ Dessuten viderefører ikke rekonstruksjonsloven kravet om minimumsdividende på 25 prosent som gjaldt for tvangsakkord ved gjeldsforhandling.

Det oppstilles heller ikke noe eksplisitt krav til at proratarisk nedskrivning må være normen for beløp som overstiger en eventuell terskel for størrelsen på kravene som omfattes av tvangsakkorden. Riktignok kan retten etter $\S 48$ første ledd nr. 1 nekte å stadfeste et rekonstruksjonsforslag dersom det «ikke er rimelig og rettferdig overfor fordringshaverne», men forarbeidene forutsetter at det ikke skal gjelde et absolutt krav om likebehandling. ${ }^{68}$ Likebehandling kan sløyfes dersom dette er nødvendig «[f]or å få til rekonstruksjonsløsninger som kan vinne tilslutning blant et bredt flertall av kreditorene og som kan legge grunnlag for god drift etter gjennomført rekonstruksjon». ${ }^{69}$

Det er uklart hva forarbeidene sikter til når det å «vinne tilslutning blant en bredt flertall av kreditorene» angis å være en legitim begrunnelse for forskjellsbehandling. Tatt på ordet kan det virke som om forarbeidene legger opp til at skyldneren kan «kjøpe stemmer» gjennom å gi utvalgte kreditorer fordelaktig behandling. En slik forståelse avkreftes imidlertid gjennom $\S$ 49 nr. 1, som gir retten hjemmel til å nekte stadfestelse dersom «det påvises at akkorden er brakt i stand ved at en fordringshaver er blitt begunstiget eller har fått løfte om begunstigelse».

En annen prioritetsregel som gjelder i konkurs, er at alminnelig usikret gjeld må dekkes fullt ut før verdier tilflyter etterstilt gjeld og selskapets aksjonærer. ${ }^{70}$ Ved rekonstruksjon ville en

\footnotetext{
${ }^{66}$ Sml. Rune Sæbø, «Revisjon av gjeldsordningsloven - harmonisering av gjeldsforfølgningsretten?», Lov og Rett 2001, s. 513-514 (s. 514).

${ }^{67}$ Rkl. § 34 annet ledd første punktum. Se imidlertid § 49 nr. 2 bokstav b, som gir retten hjemmel til å nekte stadfestelse hvis beløpene som dekkes fullt ut, er så betydelige at det innebærer en urimelig forfordeling av fordringshaverne. De tilsvarende reglene i konkursloven er $\S \S 30$ femte ledd og $50 \mathrm{nr} .2$ bokstav b.

${ }^{68}$ Prop. 75 L (2019-2020) s. 73.

${ }^{69}$ Utredningen s. 89, sitert i Prop. 75 L (2019-2020) på s. 73.

${ }^{70}$ For etterstilt gjeld fremgår dette av deknl. § 9-7, mens poenget om aksjonærer fremgår implisitt av konkurslovens system, særlig § 136.
} 
slik løsning bety at nedskrivning av alminnelig usikret gjeld bare kan skje i den utstrekning etterstilt gjeld skrives ned i sin helhet. I tillegg måtte den nedskrevne gjelden konverteres til aksjer til en kurs som fullstendig utvanner selskapets aksjonærer; ellers ender man med at etterstilte kreditorer og/eller aksjonærer beholder verdier på de alminnelige usikrede kreditorenes bekostning.

Som gruppe er de alminnelige usikrede kreditorene vernet mot tvangsakkorder som beriker etterstilte kreditorer og aksjonærer på deres bekostning. Dette skyldes at en rekonstruksjon forutsetter samtykke fra et simpelt flertall av de berørte kreditorene. Med andre ord kan ikke selskapet gjennomføre en rekonstruksjon hvor eksisterende aksjonærer beholder verdier uten at $\mathrm{i}$ det minste et flertall av berørte kreditorer samtykker. Men den enkelte kreditor er ikke vernet. Dersom et tilstrekkelig flertall støtter et rekonstruksjonsforslag, har ikke enkeltkreditorer noen ubetinget rett til å kreve at retten nekter stadfestelse av forslaget på grunn av at forslaget ikke overholder prioritetsrekkefølgen som gjelder i konkurs.

Mindretallet gis riktignok en viss beskyttelse ved at retten etter $\S 49 \mathrm{nr}$. 2 bokstav a kan nekte å stadfeste et forslag dersom «dividenden som blir tilbudt [...] står i vesentlig misforhold [...] til hvilken dekning som kan forventes ved en konkurs». Dette setter en grense for i hvilken utstrekning aksjonærer kan begunstiges på kreditorenes bekostning, i og med at det vil finnes en grense for når begunstigelse av aksjonærene vil gjøre en konkurs til et mer fordelaktig alternativ for kreditorene. I den grad det foreligger et «rekonstruksjonsoverskudd»-dvs. differansen mellom verdien av selskapet i rekonstruert stand og hva et konkurssalg av virksomheten vil kunne innbringe - er det derimot ingen av lovens bestemmelser som krever at dette skal fordeles mellom kreditorer og eksisterende aksjonærer etter samme prinsipper som ved konkurs. Dessuten gir ikke $\S 49 \mathrm{nr}$. 2 bokstav a enkeltkreditorer en ubetinget rett til å motta minst like mye som de ville ha mottatt i en hypotetisk konkurs i skyldneren. Dette i motsetning til kravene som allerede gjelder i enkelte andre lands rett og hva EUs restruktureringsdirektiv krever av nasjonal rett. ${ }^{71}$

Analysen viser at det går et markant skille mellom sikrede og fortrinnsberettigede kreditorer og usikrede kreditorer når det gjelder vern av konkursprioritet. Sikrede og fortrinnsberettigede krav kan det ikke gjøres inngrep i med mindre den enkelte kreditor samtykker. Riktignok gjør rekonstruksjonsloven $\S 19$ og panteloven $\S 6-5$ det mulig å gi nye lån prioritet foran eksisterende panteretter, men det betyr ikke at en eksisterende panterett og det underliggende pante-

71 Se EU-direktivets artikkel 10(2) bokstav d. Se også eksempelvis amerikansk rett (11 U.S.C. § 1129(a)(7)(A)(ii)) og tysk rett (Insolvenzordnung § 245(1) nr. 1). 
kravet automatisk også reduseres. Dette innebærer at det i svært liten grad er mulig å tvinge igjennom en verdiforskyvning fra sikrede kreditorer til andre kreditorer eller aksjonærene.

\section{$7 \quad$ Rekonstruksjon av konsern}

Rekonstruksjonsloven åpner ikke for en samlet behandling av flere skyldnere. Også ved rekonstruksjon må den aksjerettslige ansvarsbegrensningen og den konkursrettslige prioritetsrekkefølgen i hvert enkelt selskap som hovedregel respekteres. Dette kan skape problemer når et selskapskonsern utgjør én økonomisk enhet. I slike konserner forekommer det ofte kryssikkerheter og -garantier, dvs. sikkerheter stilt av ett konsernselskap for forpliktelsene til ett eller flere andre av konsernets medlemmer.

Det er vanlig at konserner finansierer driften gjennom at morselskapet tar opp lån fra banker eller andre eksterne långivere, og deretter låner pengene videre til andre konsernselskaper med likviditetsbehov. Långiverne vil ofte kreve at lånet sikres gjennom garantier og sikkerhetsstillelse fra konsernselskapene, et krav konserner i økende grad har kunnet etterkomme som en følge av senere års liberalisering av aksje- og allmennaksjeloven. ${ }^{72}$

Hvordan påvirker en slik finansieringsstruktur en rekonstruksjon av morselskapet? Fra gjennomgangen av rekonstruksjonsloven vet vi at det er mulig å skrive ned eller utskyte forfallet for usikrede lån ytt til morselskapet mot enkelte långiveres vilje. Loven inneholder imidlertid ingen hjemmel for på samme måte å endre långiverens rett til å gjøre gjeldende garantier og sikkerheter stilt av skyldnerens datterselskaper. Slik garantier typisk utformes, vil långiveren ha rett til å kreve det nedskrevne beløpet dekket av garantisten i samme konsern dersom kravet mot morselskapet skrives ned som ledd i en insolvensbehandling. Dette medfører at nedskrivningen av morselskapets gjeld er til liten glede for konsernet, i og med at dette utløser krav under garantier stilt av konsernselskaper: Man er like langt dersom en reduksjon i morselskapets gjeld på (eksempelvis) 10 millioner kroner resulterer i at et datterselskap må betale samme sum i henhold til en garanti stilt til långiveren.

Konsernet kan naturligvis «forsvare» seg ved at de aktuelle datterselskapene begjærer rekonstruksjon samtidig som morselskapet, og at datterselskapene fremlegger et rekonstruksjonsforslag hvor disse selskapenes usikrede garantiansvar skrives ned tilsvarende hovedkravet. Loven åpner tilsynelatende for dette: En tvangsakkord kan i utgangspunktet omfatte alle krav «som skriver seg fra tiden før åpningen av rekonstruksjonsforhandlingen» (§ 54). Selv om garantistens forpliktelse er en betinget forpliktelse frem til betingelsene for garantiansvaret

\footnotetext{
${ }^{72}$ Se lov 14. juni 2013 nr. 40 om endringer i aksjelovgivningen mv. (forenklinger) og lov 6. desember $2019 \mathrm{nr}$. 77 om endringer i aksjelovgivningen mv. (langsiktig eierskap i noterte selskaper mv.).
} 
inntrer, knytter forpliktelsen seg til en avtale inngått forut for åpningen av rekonstruksjonsforhandlingene, og garantien vil normalt også bli en aktuell forpliktelse i og med åpningen av rekonstruksjonsforhandlinger i morselskapet. Imidlertid forutsetter nedskrivning av garantiansvaret samtykke fra over halvparten av datterselskapets kreditorer. I den utstrekning garantiansvaret representerer brorparten av datterselskapets forpliktelser, som formodentlig ofte vil være tilfellet, vil ikke garantiansvaret kunne reduseres mot garantibeneficiantens (dvs. morselskapets långiver) vilje. I den grad datterselskapene har stilt realkausjon, er situasjonen enda mer håpløs, i og med at inngrep i pantesikrede krav alltid krever samtykke fra kreditoren.

Spørsmålet er om det er problematisk at ett konsernselskaps kreditorer kan blokkere en løsning som er til gunst for konsernkreditorene sett under ett. Et slikt utfall er ikke nødvendigvis uønsket de lege ferenda. Man kan fint se fraværet av slike bestemmelser som et uttrykk for at lovgiver tar på alvor at selskaper i samme konsern har selvstendige formuesforhold. Næringsdrivende har kun seg selv å takke for at de velger å drive virksomhet ved bruk av selskapsstrukturer som vanskeliggjør rekonstruksjon både innenfor og utenfor rekonstruksjonsforhandlinger. Det er jo ikke tilfeldig at enkelte kreditorer betinger seg garantier fra konsernselskaper som ikke har forpliktelser overfor konsernets øvrige kreditorer; poenget er nettopp å få en fortrinnsrett til deler av konsernets formuesmasse. ${ }^{73}$ Hvis man forutsetter at en slik finansieringsstruktur gir konserner billigere finansiering enn ellers, ser man at spørsmålet om det bør være adgang til å foreta en samlet rekonstruksjon av konserngjelden, har likhetstrekk med spørsmålet om man skal åpne for innhugg i den sterke prioriteten sikrede kreditorer har i norsk insolvensrett. ${ }^{74}$

Uavhengig av hvilket syn man har på spørsmålet om loven i større grad bør tilrettelegge for restrukturering av konsern, virker det klart at lovens nåværende tilnærming vil gjøre det utfordrende å restrukturere konserner.

\section{Konklusjon}

Den ovenstående gjennomgangen viser at det er flere forhold ved rekonstruksjonsreglene som gjør at mange selskaper sannsynligvis vil finne det mer formålstjenlig å restrukturere konkurstruede virksomheter på andre måter enn ved hjelp av rekonstruksjonsloven. De to mest nærliggende alternativene til rekonstruksjon er, for det første, å slå selskapet som driver virksomheten, konkurs, for deretter å kjøpe nødvendige eiendeler fra konkursboet og drive virksomheten videre med et nytt selskap som eier. Et annet alternativ er å gjennomføre en avtalebasert restrukturering. De etter vårt syn tre praktisk viktigste begrensningene i rekonstruksjonsloven

\footnotetext{
${ }^{73}$ Kenneth Ayotte, «Disagreement and Capital Structure Complexity», Journal of Legal Studies, 2020, s. 1-32.

${ }^{74}$ Se punkt 4.4.
} 
ligger i reguleringen av forholdet til de sikrede kreditorene, muligheten til å gjøre noe med løpende avtaleforhold, og manglende regler for å håndtere rekonstruksjon i konsernforhold.

Vernet av sikrede kreditorer innebærer at rekonstruksjon først og fremst er nyttig for to typer skyldnere. Den første gruppen omfatter skyldnere som ikke er avhengige av å skrive ned sikret gjeld for å overvinne sine finansielle problemer, og dermed kan begrense rekonstruksjonsforslaget til å omfatte usikret gjeld. Dette er trolig en snever gruppe: I og med at fremmedkapitalfinansieringen av norsk næringsliv i stor grad består av banklån, er andelen av norske selskaper hvis gjeldsfinansiering kun er usikret, generelt sett lav. Andelen er trolig enda lavere blant selskaper som har en virksomhet av et stort nok omfang til at det er regningssvarende å pådra seg den kostnaden gjennomføringen av en rekonstruksjonsforhandling innebærer. Som vi var inne på i punkt 4.3, er det dessuten grunn til å anta at selskapene som innleder rekonstruksjonsforhandlinger - og dermed tilfredsstiller åpningsvilkåret om «alvorlige økonomiske problemer»-som oftest allerede har pantsatt det som kan pantsettes.

En annen gruppe skyldnere som kan dra nytte av rekonstruksjonsforhandlinger, er de som $\emptyset n s k e r$ å fremsette et forslag som har støtte hos samtlige sikrede kreditorer, men som kun har støtten til et flertall av berørte usikrede kreditorer. I dette tilfellet vil rkl. $§ 42$ kunne muliggjøre at rekonstruksjonsforslag går igjennom til tross for at et mindretall av de usikrede kreditorer skulle være imot. Sammenlignet med utenrettslige forhandlinger gjør rkl. § 42 det mulig å gjennomføre en restrukturering i situasjoner hvor forhandlingene er fastlåste. Dessuten gjør rkl. § 42 det enklere å fordele byrdene ved restruktureringen på flere parter enn dem som normalt deltar i utenrettslige løsninger - banker, obligasjonseiere og aksjonærene. Etter rekonstruksjonsloven kan også leverandørgjeld og skatte- og avgiftskrav trekkes inn for å bære noe av byrden som hittil har blitt båret av eiere av usikrede obligasjoner.

Rekonstruksjonsloven er av liten nytte for selskaper som tynges av høye driftsutgifter. Punkt 5.2 viste at en tvangsakkord er et dårlig egnet virkemiddel for å endre vilkårene under løpende avtaler i skyldnerens favør. Alt annet likt vil en utvidelse av reglene til også å tvinge igjennom endringer av løpende avtaler til skyldnerens gunst føre til at flere selskaper kan unngå konkurs gjennom rekonstruksjon. Av denne grunn har enkelte tatt til orde for at slike avtaler bør kunne omfattes av en tvangsakkord hvis de er «uforholdsmessig tyngende». ${ }^{75}$ Av plasshensyn skal vi ikke her gå inn på om dette synspunktet har noe for seg. Vi nøyer oss med å påpeke at vi her står overfor et grunnleggende spørsmål om hva man ønsker at rekonstruksjonsregelverket skal være. Den nåværende tilnærmingen er å lempe på kravene til hvem som må samtykke for å

\footnotetext{
${ }^{75}$ Stine D. Snertingdalen og Helge Østvold, «Ny midlertidig rekonstruksjonslov», Revisjon og Regnskap 2020, s. $19-21$.
} 
redusere gjelden, og dermed sikre den videre eksistensen til selskaper hvis drift er eller forventes å bli lønnsom. ${ }^{76}$ Skal man beholde og eventuelt videreutvikle denne målsettingen, eller skal man tilrettelegge for at selskaper kan beholde tilgang til lokaler, arbeidskraft og andre driftskritiske ressurser selv om de ikke har råd til å betale rådende markedspris? Hvis man velger denne sistnevnte tilnærmingen, vil lovgivningen gå fra å sikre den videre eksistensen til selskaper med finansielle problemer til også å beskytte videre drift av virksomhet som lider av $\varnothing$ konomiske problemer, dvs. at selve driften ikke er tilstrekkelig lønnsom. ${ }^{77}$ Dette vil i sin tur kunne gi opphav til spørsmål om restruktureringslovgivningens innvirkning på markedskonkurransen.

Rekonstruksjonsloven opphører å gjelde 1. januar 2022. Det er grunn til å tro at EUs restruktureringsdirektiv rundt samme tid vil bli inntatt i EØS-avtalen. Direktivet er ikke et totalharmoniseringsdirektiv, ${ }^{78}$ og medlemsstatene kan velge mellom alternative løsninger på flere viktige spørsmål. Sagt med andre ord vil vedtakelse av norsk implementeringslovgivning ikke kun dreie seg om sandpåstrøing. Man står nå overfor en gyllen mulighet til å gjøre en grundig vurdering av hvordan man $\emptyset$ nsker at norsk rekonstruksjonslovgivning skal være i fremtiden. Det er all grunn til å håpe at Regjeringen vil gripe denne muligheten ved å oppnevne et offentlig utvalg for å utrede disse viktige spørsmålene.

\footnotetext{
${ }^{76}$ Se Prop. 75 L (2019-2020) s. 12.

${ }^{77}$ Om skillet mellom finansielle og økonomiske problemer, se Altman, Hotchkiss og Wang 2019 s. 8.

${ }^{78}$ Om totalharmoniseringsdirektiver, se Fredrik Sejersted m.fl., EØS-rett, 3. utg., Oslo 2011 s. 299-300.
} 